\title{
DISQUALIFICATION OF COMPANY DIRECTORS IN KENYA
}

\section{Dr Kiarie Mwaura, Lecturer in Law, Queen's University Belfast ${ }^{1}$ \\ INTRODUCTION}

Disqualification of directors protects the public by placing a prohibition on a miscreant director being involved, for a specific period, in the management of companies. ${ }^{2}$ In addition, disqualification orders serve as a deterrent to those who might be tempted to engage in fraudulent activities. ${ }^{3}$ Therefore, where a director breaches his obligations and, as a result, occasions loss to creditors, the public interest requires that the misconduct be punished by disqualification. ${ }^{4}$

Given that the State has the responsibility of providing an unbiased commercial environment, which ensures that the formation of companies takes place smoothly and that the public is protected from miscreant directors, there is a need to balance these conflicting interests for the sake of a healthy economy. Although strict regulations in relation to the disqualification of directors may ensure that unfit directors do not serve on boards, it is undoubtedly the case that over-regulation or stringent disqualification proceedings may result in fewer people being interested in serving as directors. This would in turn adversely affect the economy, as few companies would be able to attract appropriate and competent directors.

Although shareholders generally decide who sits on a board of a company, some exceptions regarding the people they can choose are imposed by Parliament. The Companies Act ${ }^{5}$ (the "Act") contains some provisions that prescribe those who are able to act as directors. ${ }^{6}$ As shareholders are not always able to prosecute errant directors, disqualification provisions supplement other provisions that seek to protect creditors and other stakeholders. $^{7}$

${ }^{1}$ I am grateful to Professor Andrew Keay, Peter Walton and David Capper for comments on an earlier draft of this article. Responsibility for any errors or omissions remains with the author.

2 S. Griffin, Personal Liability and Disqualification of Company Directors, (Hart, 1999) p 131.

3 v Kazmi (1984) 7 Cr App Rep 115, at 116.

4 Per Vinelott J in Re Stanford Services [1987] BCLC 607, at 620.

5 Cap 486, Laws of Kenya.

6 The Act makes provisions for share qualifications of directors (s 183), minimum age of appointment (21 years, s 186), disqualification of undischarged bankrupts ( 188), restraint on fraudulent persons from managing companies (s 189), and disqualification of persons of unsound mind and absence from meetings of directors for six months (Table A, art 88).

7 In view of the difficulties encountered by minority shareholders in pursuit of errant directors, directors are unlikely to be accountable for their defaults unless the board changes hands or the company goes into liquidation. See Hicks, "Disqualification of Directors-Forty Years On" [1988] JBL 27, at 28. 
Despite the existing requirements for the appointment of directors ${ }^{8}$ and the disqualification provisions, companies have been run, especially during the last regime of the KANU Government, by incompetent, negligent, and fraudulent directors who have contributed to the insolvency of other companies. ${ }^{9}$ Some 45 parastatals and other companies in which the Government has shares have been placed in receivership since 1980. Some of the directors who were responsible for the collapse of such companies were not only been appointed to other directorships, they were also appointed to the Cabinet. ${ }^{10}$

For instance, despite the public outcry and prosecution ${ }^{11}$ that followed the investigation of the former managing director of Kenya Posts and Telecommunications (KPTC), Mr Kipng'eno Arap Ng'eny, for masterminding the loss incurred by the corporation, he was retired in 1993 and appointed to head the Kerio Valley Development Authority. ${ }^{12}$ According to the 1990/91 Auditor General's Report on the Kenya Posts and Telecommunication, the managing director was responsible for a number of fraudulent dealings. First, in 1985, the corporation lost 9 million Kenyan Shillings $(£ 90,000)$ after making payments to a firm of advocates to wind up the former Kenya External Telecommunications Corporations (KETC). The payment was made despite the fact that KETC was in the process of being merged with KPTC. ${ }^{13}$ The winding-up process was rendered a sham when the two companies merged. Secondly, by $30^{\text {th }}$ June 1990 , the corporation had failed to remit to various public authorities statutory deductions from staff salaries amounting to 176.5 million Kenyan Shillings $(£ 1,765,000) .{ }^{14}$

Despite several recommendations made by the Parliamentary Public Investment Committee that the people it adversely named should be charged in court and barred from holding public offices, such individuals continued to serve in high positions both in the government and the private sector. ${ }^{15}$ As a result of such irregularity, the Public Investment Committee proposed that legislation should be enacted to enable Parliament to vet all nominees for the leadership of parastatals. ${ }^{16}$ The Committee in its Ninth Report highlighted the weaknesses of the present regulatory framework by citing the example of the former chief executive of the Nyayo Tea Zone Development Corporation, Mr Isaiah Cheluget, who had failed to pay money owed to the corporation despite numerous attempts by Parliament to recover the money from him.

8 According to ss 183 (1) and 186 of the Act, directors must be natural persons, they must have share qualifications, and minors may not be appointed as directors.

9 “45 parastatals, Govt firms in receivership" East African Standard, 12 July 2001.

10 Ibid.

11 He was charged with fraud on July 17, 2000. See "Drama as Ng'eny is Finally Charged" East African Standard, 18 July 2000.

12 His prosecution followed the recommendations made by the Parliamentary Public Investments Committee. See "Minister Quizzed on Sh 250 Million" Daily Nation, 1 June 2000.

13 K. Kibwana et al, The Anatomy of Corruption in Kenya: Legal, Political and Social-Economic Perspectives (1996) p 73.

14 Ibid.

15 Leakey, "Wako Grilled by PIC", East African Standard, 9 March 2000.

16 "New 'List of Shame' Tabled in Parliament", East African Standard, 28 July 2000. 
Despite this default he was subsequently appointed a commissioner with the Electoral Commission of Kenya. ${ }^{17}$ As the Daily Nation notes:

"The tragedy in Kenya is that those who have mismanaged the Government, the Development Finance Institutions, and even multinational corporations are those who continue to circulate in and out of Government as ministers, assistant ministers, advisers and so on." 18

Such cases have done much to reduce the confidence of investors. In fact, a survey conducted by the author in 2001 revealed that disqualification orders in Kenya are extremely rare. ${ }^{19}$ It is against this backdrop that this article examines whether the disqualification restrictions provided for by the Act are adequate to protect the interests of the corporate entity, creditors, and other stakeholders. The article also assesses measures that can be adopted by the new Kenyan government to prevent miscreant individuals from serving as directors.

\section{Grounds For Disqualification}

In Kenya, a director must cease to be a director if he fails to take up any prescribed shares within two months of his appointment. ${ }^{20}$ A director is automatically disqualified if he becomes an undischarged bankrupt or if he makes any arrangement or composition with his creditors generally. ${ }^{21}$ Other grounds, which necessitate disqualification of directors, include whether he is prohibited from being a director by reason of any order made under section 189. This section restrains fraudulent persons from managing companies. Further grounds for disqualification contained in the Act include: where a director is of unsound mind; ${ }^{22}$ where he resigns his office by notice in writing to the company; ${ }^{23}$ or he is absent without permission for more than six months from meetings of the directors held during that period. ${ }^{24}$

\section{Bankrupts}

Persons who are undischarged bankrupts are barred from acting as directors under the Act. The Act provides:

"If any person who has been declared bankrupt or insolvent by a competent court in Kenya or elsewhere and has not received his discharge acts as a director of, or directly or indirectly takes part in or is concerned in the management of, any company except with the leave of the court, he shall be liable

17 “Probe M'Mukindia, Kiplagat-PIC", East African Standard, 29 July 2000.

18 Nyong'o, "How Bad Governance Strangles Business", Daily Nation, 10 June 2001.

19 Mwaura, "Regulation of Directors in Kenya: An Empirical Study" [2002] 13 International Company and Commercial Law Review 465, at 478.

20 The Act, s 183.

21 Ibid, s 188.

22 Article 88 (d), Table A.

23 Ibid, art 88 (e).

24 Ibid, art 88 (f). 
to imprisonment for a term not exceeding two years or to a fine not exceeding ten thousand shillings or both." 25

As people who have failed to manage their finances, bankrupts are automatically disqualified from taking part in the management of companies. As such, their disqualification is not dependent upon wrongdoing, negligence, or the making of a disqualification order by the court. However, a bankrupt may apply to court for leave to act as a director. ${ }^{26}$ For leave to be granted, the bankrupt must show that he or she may be safely involved in the management of companies. ${ }^{27}$

Acting as a director while disqualified results in criminal penalties and personal liability ${ }^{28}$ for the debts and other liabilities of any company in whose management a disqualified person was involved. ${ }^{29}$ The personal liability extends to any person involved in the management of the company who knowingly acts on the instructions of a disqualified person. ${ }^{30}$

In the UK, the Company Directors Disqualification Act $1986^{31}$ (hereinafter referred to as "CDDA") prohibits individuals who are undischarged bankrupts from acting as directors. ${ }^{32}$ A director can also be disqualified on grounds of unfitness for entrusting the management of a company to someone known to be bankrupt or disqualified. ${ }^{33}$ Apart from the automatic disqualification of undischarged bankrupts, all other grounds for disqualification require a court order specifying the duration of disqualification. ${ }^{34}$

Disqualifying bankrupts from managing companies is helpful as it prevents them from starting a business and raising credit using a limited liability company. ${ }^{35}$

25 The Act, s 188 (1).

26 Ibid.

27 S $188(2)$.

$28 \mathrm{~S} 188(1)$.

29 S 323(1).

30 The Act states "any persons who were knowingly parties to the carrying on of the business in the manner aforesaid shall be personally liable." See s 323 (1) (a) ibid.

31 The UK government introduced the Act to curb abusive practices as it was adopting a free market philosophy. The new laws were meant to punish miscreant directors and thereby deter misconduct. They were also aimed at facilitating screening so as to make it difficult for unsuitable individuals to run companies and in turn protect the public. Between 1998 and 1999, 1,284 disqualification orders were made under s 6, 20 under s 8, and 178 under the other provisions of the Act. See B.R. Cheffins, Company Law, Theory, Structure, and Operation (1997) p 551; S. Mayson et al, Company Law (17 ${ }^{\text {th }}$ ed, 2000) p 720.

32 Ss 2 \& 11.

33 Re Moorgate Metals Ltd [1995] 1 BCLC 503.

34 The Insolvency Bill 1985 unsuccessfully attempted to introduce automatic disqualification where a director has been involved in more than one insolvent company. See Parry, "Personal Insolvency as a Restriction on Involvement in Company Management" [1999] Insolvency Lawyer 199, at 200

35 Hicks, supra n 6, at 30. 


\section{Management of the Company}

The Act requires the court, in its discretion, ${ }^{36}$ to disqualify a person who is guilty of an offence as a director or promoter of a company, or is in any way, whether directly or indirectly, concerned or participating in the management of a company. The Act provides thus:

"Where a person is convicted of any offence in connection with the promotion, formation or management of a company; or in the course of a winding up a company it appears that a person has been guilty of any offence for which he is liable (whether he has been convicted or not under section 323); or has otherwise been guilty, while an officer of the company, of any fraud in relation to the company or of any breach of his duty to the company, the court may make an order that the person shall not, without leave of the court, be a director of or in any way, whether directly or indirectly, be concerned or take part in the management of the company for such period not exceeding five years as may be specified in the order." 37

The phrase "in connection with management" does not only refer to offences involving misconduct in the company's affairs, but includes the entire purpose for which the company exists. ${ }^{38}$

The provision is somewhat vague, as it is possible for a wide range of people, including employees in the lower cadre of the company, to be involved in indirect management. This makes it difficult for a disqualified person to ascertain what role he might assume once a company employs him. ${ }^{39}$ For instance, since the concept of management involves policymaking and decision-making activities which affect the company as a whole, or a substantial part of it, and which may affect its financial standing, ${ }^{40}$ a management consultant advising on financial management may be said to be concerned in the management of the company for the purposes of disqualification. ${ }^{41}$

36 Disqualification arising from such grounds is automatic in some jurisdictions, such as Australia. As such, a director, when applying for leave to act, bears the burden of proving why the order should not be made. For a detailed analysis on automatic disqualification see Australia's Corporations Act 2001, s 206B; Hicks, "Making and Resisting Disqualification Orders" (1987) 8 Co Law 243.

37 S 189(1).

$38 R$ v Austen (1985) 7 Cr App R 214. Since it is difficult to formulate a rule, which would adequately cover all wrongdoing related to the company, Drake argues that disqualification on such grounds should be reserved for the Articles. See Drake, "Disqualification of Directors - "The Red Card" [1989] JBL 474, at 477.

39 In Re Altim Pty Ltd [1968] 2 NSWLR 762 the applicant wanted leave of the court to be in charge of the New South Wales branch of a company making window frames. This was assumed to be a function of the management and the court refused to grant leave to take the job.

40 Commissioner for Corporate Affairs v Bracht [1989] VR 821.

$41 \quad R$ v Campbell [1984] BCLC 83. 
As a result, full disqualification might not only remove a person from the board ${ }^{42}$ but also make him unemployable. ${ }^{43}$ Although a person may apply for a declaration or for leave to act, there can be no doubt that the slow and expensive judicial process would adversely affect directors who have been automatically disqualified. ${ }^{44}$ Therefore such a broad disqualification is clearly inappropriate if it occurs automatically. ${ }^{45}$

\section{Fraud}

The Act provides for disqualification as a result of fraud. A court may disqualify a person from taking part in the management of a company if a person is "convicted of any offence in connection with the promotion, formation or management of a company." 46 A person can also be disqualified if, in the course of winding up of a company, it appears that he, while an officer of the company, has been guilty "of any fraud in relation to the company or of any breach of his duty to the company." 47

In contrast to the Act, the Ghanaian Companies Code provides for disqualification on the basis of conviction of any offence (not necessarily relating to a company) involving fraud or dishonesty. The conviction need not be in Ghana. Similarly, Singapore, in 1967, adopted the Australian version of disqualification for criminal offences ${ }^{48}$ to cover not only offences in connection with the promotion, formation or management of corporations, but also offences involving fraud or dishonesty not connected with the company, where the maximum penalty is more than three months imprisonment, whether imposed or not.

Sufficient grounds, rather than mere allegation of fraud, need to be established in order to prove fraud under the Act. The onerous duty of proving fraud was illustrated in the case of Kassam Ebrahim v Tait ${ }^{49}$ where the Official Receiver applied under section 196 of Uganda's Companies Ordinance $^{50}$ for the public examination of company directors, Kassam Ebrahim and Mohamedali Damji. The company, Kassam Ibrahim \& Co Ltd, was incorporated for the purposes of taking over a business formerly carried on in partnership involving the two directors. The Official Liquidator alleged that the partnership was insolvent at the time that the company was formed. The liquidator therefore sought to have a public examination of the

42 The Ghanaian Code imposes specific restrictions to prevent errant directors from being concerned in company management even when he is not a director. See s 186 (1) (b) Ghana's Companies Code.

43 Where disqualification does not disqualify a director from serving a corporation as an employee, it cannot be said to have the effect of taking their livelihood away. See Leigh, "Disqualification Orders in Company and Insolvency Law" (1986) 7 Co Law 179, at 183.

44 Automatic disqualification may be justified in cases of personal insolvency and criminal offences. See Hicks, supra n 6, at 41.

45 Automatic disqualification was rejected in England and Singapore. See Hicks, ibid n 6, at 41 .

46 S 189(1).

47 S 189(1)(b)(ii).

48 Singapore Companies Act, s 154.

49 [1935] EACA 51.

50 Cap 105. 
directors on the basis that the incorporation was fraudulent on the creditors of the company. He also sought to recover two sums of money that were said to have been received by the directors from the company, and to hold them personally liable for the debts of the company. Finding that the Official Receiver had failed to prove fraud, Law CJ followed the judgement of Lord Halsbury in Ex parte Barnes,${ }^{51}$ which provided that:

"In order to give the Court jurisdiction to make such an order, there must be a finding of fraud, and a finding of fraud against an individual who is thereby made subject to being summoned before the court. . . I do not mean that the particular word 'fraud' must be used, but that such facts must be found by the Official Receiver as suggests fraud against the person incriminated: and that there must be an individual person incriminated: it is not enough that there is a general finding that fraud must have existed somewhere, which would mean nothing." 52

One reason persuading Law $\mathrm{CJ}$ that fraud had not been proved was that the money received by Kassim Ebrahim from the company as part of the purchase price of his interest in the partnership business did not raise any suspicion. Moreover, the Receiver did not show when the sum was received, what the capital of the company was, and how the formation of the company constituted fraud on the creditors. ${ }^{53}$

As a result of the onerous burden of proving fraud in Kenya, disqualification, only on grounds of fraud when a company is a going concern, might be insufficient to ensure commercial propriety and foster an appropriate business environment. This reason led the UK's Cork Committee to favour disqualification based on the wrongful acts of directors rather than fraud..$^{54}$ Thus section 214 of the Insolvency Act 1986 followed as a result of the recommendations of the Committee. A director therefore becomes liable for the wrongful trading of the company where the company has gone into insolvent liquidation and at some time before the commencement of the winding up of the company the director knew or ought to have concluded that there was no reasonable prospect that the company would avoid going into insolvent liquidation. A liquidator may apply to the court for a

51 [1896] AC 146.

52 Ibid, at 152.

53 [1935] EACA 51, at 57.

54 S 188 of the UK's Companies Act 1948 gave courts the power to disqualify a director following conviction for fraud in the operation of a company. This was widened by the Companies Act 1976 s 28(1), which allowed disqualification for persistent default. S 3 of the Companies Act 1981 extended the provision further by empowering the making of disqualification orders to liquidators, receivers, and managers of the property of a company. All the provisions were consolidated in the Companies Act 1985 s 300, which preceded the Company Directors Disqualification Act 1986. Although a director had to be associated with two successive insolvencies before he could be disqualified under s 300, he may now be disqualified under s 6 of the 1986 Act if the court is satisfied that he has been a director of a company which has at any time become insolvent (whether while he was a director or subsequently) and that his conduct as a director of that company makes him unfit to be concerned in the management of a company. 
declaration that a person who is or has been a director is liable to make a contribution to the assets of the company. However, it is a defence for a director to show that he took every step with a view to minimising the potential loss to the creditors of the company. A disqualification order may also be made against a director found liable for wrongful trading. ${ }^{55}$

It is not possible for a director to be disqualified in Kenya unless he been convicted of an offence in connection with the promotion, formation, or management of a company; or the company is in the process of being wound up and it appears that a director is guilty of any fraud or breach of duty in relation to the company. ${ }^{56}$ This provision renders it impossible to disqualify directors for breach of duties when a company is a going concern. Thus, broadening the scope of section 189 (1) to provide for disqualification arising from breaches of duty when a company is a going concern would make it more of a deterrent. This may be achieved by disqualifying directors on the basis of their unfitness to act in the management of companies, a ground which is applied in the UK. This ground of disqualification is considered in the following section.

\section{Unfitness}

A director in Kenya cannot be disqualified ${ }^{57}$ for being unfit to be involved in the management of a company. Thus, whilst breach of duty is a sufficient ground for disqualification if a company is in the course of winding up, ${ }^{58}$ fraud needs to be proven for a director to be disqualified when the company is a going concern. ${ }^{59}$ In contrast, a director in the UK can be disqualified under section 8 of the CDDA for being unfit ${ }^{60}$ when the company is a going concern. The Secretary of State can make an application under this section for a disqualification order where it appears to him, from an Inspector's report, that it is necessary in the public interest to have the director declared unfit. In such an event the court can exercise its discretion to make a disqualification order where it is satisfied that the conduct of a director in relation to the company makes him unfit to be concerned in the management of a company.

In the UK, the CDDA makes it compulsory for a judge to make an order, under the unfitness ground, if the terms of the legislation are satisfied. ${ }^{61}$ For a director to be declared unfit, the court must be satisfied that the director has exhibited gross incompetence or conduct in breach of commercial morality

CDDA, s 10 .

56 S 189(1) of the Act.

$57 \mathrm{~S} 6$ of the CDDA obliges the court to make a disqualification order against an individual if it is satisfied that he is or has been a director of a company which has become insolvent and that his conduct as a director of that company makes him unfit to be concerned in the management of a company.

58 The Act, s 189(1)(b)(ii).

59 S 189(1).

60 In determining whether a director is unfit under both sections, $\mathrm{s} 9$ obliges the court to have regard to matters mentioned in Part I of Sch I. In case the company has become insolvent, the court must have regard to matters mentioned in Part II of Sch 1.

61 Under both ss 6 and 9. 
that constitutes a danger to the public. ${ }^{62}$ This may arise, for instance, where a director conducts business in total disregard of the interests of creditors. In Re Ipcon Fashions Ltd $^{63}$ knowledge by the director that the company was insolvent when he siphoned off its business to another company, incurring liability to the old company, was held to be a ground for disqualification. Similarly, in Re McNulty's Interchange Ltd ${ }^{64}$ a director who had no new ideas about improving the business of a company, which was continuously accumulating debts, was liable for disqualification. ${ }^{65}$ Explaining what makes a person unfit in the UK, Sir Nicolas Browne-Wilkinson VC said in Re Lo Line Electric Motors Ltd:

"Ordinary commercial misjudgement is in itself not sufficient to justify disqualification. In the normal case, the conduct complained of must display a lack of commercial probity, although I have no doubt that in an extreme case of gross negligence or total incompetence disqualification could be appropriate." 66

The courts have, therefore, refused to disqualify directors for mere mismanagement, as the aim of disqualification is the protection of the public and not punishment of directors. ${ }^{67}$ It therefore follows that despite the mandatory nature of section 6 of the CDDA, the courts may decline to disqualify a director in the absence of sufficient evidence to prove unfitness. $^{68}$ Although the courts assess whether a director should be disqualified on the balance of probabilities, the amount of evidence required to find a director liable is often more onerous than that, ${ }^{69}$ as the evidence required in practice extends the standards of proof beyond the normal civil one. Given that the application of the balance of probabilities test would lead to disqualification of many directors, the onerous standard of proof is

62 Per Hoffmann J in Dawson Print Group Ltd [1987] BCLC 601. In assessing unfitness the court, by virtue of s 6(1)(b) considers the conduct of the director in relation to that company and any other company or companies. For more details see Hicks, supra n 6, at 33.

63 (1989) 5 BCC 733

64 (1988) 4 BCC 533.

65 In Re Douglas Construction (1988) 4 BCC 553 a director had put a lot of his own money into the company in order to keep it going and was held not to have contravened the principles of business morality. Hoffmann $\mathrm{J}$ in Dawson Print Group Ltd [1987] BCLC 601 found a director not liable for failing to pay debts due to the Crown and continuing to trade when he ought to have known that the company was insolvent. This was different from the judgement of Vinelott $\mathrm{J}$ in $R e$ Stanford Services Ltd (The Times, 29 April 1987) where he found the commercial test unhelpful and disqualified a director for two years for using money collected as VAT or PAYE as part of their cash flow needs.

66 [1988] Ch 477, at 486.

67 Per Henry LJ in Re Grayan Building Services Ltd [1995] BCC 554, at 577.

68 In Re Arctic Engineering Ltd (No 2) [1986] BCLC 253 persistent defaults by an accountant in making necessary returns did not result in disqualification since there was no dishonesty.

69 Laddie J in Re Living Images Ltd [1996] 1 BCLC 348 favoured the view that the evidence against a director ought to be overwhelming rather than indicative of the director's wrongdoing. 
thus applied in favour of directors so as to ensure that they can continue to run companies where risk is not apparent. ${ }^{70}$

While assessing unfitness, the courts examine the role of directors in making the company insolvent. For instance, the failure to provide goods and services which have already been paid for, giving preference to one group of creditors over another ${ }^{71}$ or entering into a transaction at an undervalue would be pointers to unfitness.

\section{Incompetence}

In Australia, a disqualification order can be made where a director acts dishonestly or fails to exercise reasonable care. ${ }^{72}$ As such, a conviction is not a prerequisite for a disqualification order. The courts and the Australian Securities and Investments Commission require the respondent to show why he should not be disqualified. ${ }^{73}$ This involves assessing matters of incompetence or breach of duty. Similarly, in New Zealand a disqualification order can be made in a case where a director has acted in a reckless and incompetent manner. ${ }^{74}$

In the UK, the Jenkins Report of $1962^{75}$ proposed that directors ought to be disqualified if they had acted in an improper, reckless or incompetent manner in relation to the affairs of a company. ${ }^{76}$ Although it was argued that this proposal was excessive on the basis that the standard required to prove recklessness and incompetent behaviour is not as high as that for proving unfitness, the test is used in the assessment of unfitness following insolvent liquidations in cases involving consideration of questions of commercial incompetence. ${ }^{77}$

In assessing both recklessness and incompetence, ${ }^{78}$ courts pay attention to the need to allow directors to take commercial risks. For instance, seeking and acting on competent outside advice ${ }^{79}$ in the event of financial difficulties ${ }^{80}$ is

70 Griffin, "Standards of Proof Applicable to s 6 of the Company Directors Disqualification Act 1986" (1997) 18 Co Law 24, at 25; Hoey, "Disqualifying Delinquent Directors" (1997) 18 Co Law 130, at 132.

71 Paying only those creditors who pressed for payment and taking advantage of those who did not in order to provide the working capital has been held to amount to unfitness. See Re Sevenoaks Stationers Retail Ltd [1991] Ch 164 (CA).

72 S 206F (1) (c) empowers the Australian Securities and Investments Commission to disqualify a person from managing corporations for up to five years if the Commission is satisfied that disqualification is justified.

73 For UK, see CDDA, s 8.

74 New Zealand's Companies Act 1993, s 383.

75 Report of the Company Law Committee (June 1962, Cmnd 1749), paras 80 - 85.

76 The Report had proposed that a series of insolvent liquidations would be a pointer. See Hicks, supra n 6, at 43.

77 For a detailed analysis see, S. Griffin, supra n 1, p 171.

78 Ibid, p 169.

79 Although the CDDA was effective in dissipating public dissent in respect of directors misconduct, it has been criticised for discouraging the best directors from assuming directorships and usage of company expenses by directors to hire expensive professional advisers, rather than attempting to solve the problem, to the detriment of shareholders and creditors. See B.R. Cheffins, supra n 30, p 552; 
evidence of competence even when the advice does not forestall the insolvency of a company. ${ }^{81}$ Given that directors would always be found liable for negligence if any collapse of business was treated as evidence of negligence, consideration of the risks they take gives them room to manage companies without interference. ${ }^{82}$

Although breach of duty is a sufficient ground for disqualification when the company is in the course of winding up in Kenya, the unfitness ground in the UK is more appropriate, as it is wider. For instance, the company does not have to be in the course of winding up for the unfitness ground to be applied under section 8 of the CDDA. The unfitness ground also introduces a desirable application of objective standards, ${ }^{83} \mathrm{such}$ as breach of commercial morality, gross incompetence, recklessness, and being a danger to the public, by which to judge the conduct of directors. ${ }^{84}$ Therefore, whilst a director who fails to monitor and supervise delegated activities would escape liability for being judged subjectively in Kenya, he can be disqualified on the ground of unfitness in the UK. ${ }^{85}$ The application of objective standards has, in effect, raised the standards of skill and care in the UK. ${ }^{86}$

The provisions in Singapore, UK, and Australia therefore adopt a wider scope than that of the Act. The fact that the Singapore and Australian Acts disqualify directors automatically without requiring a disqualification order from the court makes the enforcement easier by speeding up the disqualification process. The onus is usually on the disqualified person to apply to court for leave to direct a company. ${ }^{87}$

\section{Filing Returns}

In Kenya, whilst the failure to file annual returns by a director makes a director liable to a fine, ${ }^{88}$ it is not a ground for disqualification. However, in the $\mathrm{UK}^{89}$ and Australia ${ }^{90}$ the courts can disqualify a director for up to five

B. Pettet, Company Law (2001) p 453; Hicks, “Advising on Wrongful Trading: Part 2" (1993) 14 Co Law 55, at 58.

80 In the event of disqualification arising after the liquidation of a company, it is the creditors who bear the costs of disqualification proceedings as the office holder in charge is paid out of the company's assets in priority to all other claims. Despite not benefiting from directors' disqualification, creditors are made to bear such costs. Where directors contest disqualification orders a great deal of legal expenses are usually expended. See CDDA, s 7 (3), Insolvency Act 1986 s 115.

81 Re Douglas Construction Services Ltd [1988] BCLC 397.

82 P.L. Davies, Gower's Principles of Modern Company Law, (1997) p 686. In Re Richborough Furniture Ltd [1996] 1 BCLC 507 a director was disqualified for three years for lack of experience, knowledge, and understanding.

83 The application of objective standards is illustrated in Secretary of State for Trade and Industry v Ball [1999] 1 BCLC 286.

${ }^{84}$ For a detailed analysis of the standards see Dine, "Disqualification of Company Directors" (1988) 9 Co Law 213; Re Dawson Print Group Ltd [1987] BCLC 601; and Re Stanford [1987] BCLC 607.

85 Re Barings Plc (No.5) [1999] 1 BCLC 433.

86 Re D'Jan of London Ltd [1994] 1 BCLC 561, per Hoffmann LJ. See also Walters, "Directors' Duties: The Impact of the CDDA of 1986" [2000] 21 Co Law 110.

87 Hicks, supra n 6, at 33.

88 The Act, s 125(3).

89 CDDA 1986, s 3. 
years for being in default of filing returns with the Registrar of Companies. Although the failure to comply with the reporting requirements of legislation, such as failure to file annual accounts, produce audited accounts, and to maintain proper accounting standards, is a separate ground for disqualification in the UK, it is also an indicator of unfitness. A director is liable to disqualification under this section if breaches occur persistently. ${ }^{91}$ In contrast to the UK provision, the Australian provision is of wider scope, as it covers all breaches of companies legislation, rather than only those dealing with the filing of returns or other documents.

Given that disqualification under this head may improve the level of compliance in filing, it raises the accountability of directors to shareholders because shareholders and others are able to keep track of the affairs of the company. It is, therefore, to be supported for inclusion in the Act.

\section{The Length Of Disqualification Orders}

Under section 189 a disqualified director is prevented from being involved in the management of companies for a period not exceeding five years. Other jurisdictions have recognised the need for longer periods of disqualification. For instance, Australian courts can disqualify a person from managing corporations for a period that the Court considers appropriate. ${ }^{92}$ The UK's CDDA imposes a minimum disqualification for unfitness of two years and a maximum of fifteen years. ${ }^{93}$

The Nigerian Law Reform Commission of 1987 recommended that directors who have been convicted of company related offences or any other offences should be disqualified for a mandatory ten years after conviction. ${ }^{44}$ Five years disqualification after conviction was found to be too lenient. The Nigerian Commission rejected the Jenkins ${ }^{95}$ proposals to the effect that a person who has persistently failed to comply with the Act should be disqualified for a further five years after release from prison, on the basis that it was excessive and could therefore deter even the best people from accepting directorships. The Commission also recommended the broadening of the range of the persons disqualified to include infants less than 18 years. ${ }^{96}$ Furthermore, it took the view that it was necessary to utilise a mandatory disqualification on the basis that a discretionary one could still enable

90 Corporations Act 2001, ss 4, 10, 285.

91 Breaches are said to occur persistently if it is shown that a person has been convicted in more than three instances within five years for failing to provide information. See s 3(2) and (3), CDDA 1986; Re Artctic Engineering Ltd [1986] 1 WLR 686.

92 Corporations Act 2001, s $206 \mathrm{C}$ and 206 E.

93 Under s 6 CDDA. In assessing the appropriate length of the disqualification order, the court considers: the nature of the offence, whether it was closely connected with management, the nature of the person's involvement in the offence, his general character and reputation etc. See Hicks, supra n 35, at 246.

94 Nigeria Law Reform Commission, Working Papers on the Reform of Nigerian Company Law: Volume 1-Review and Recommendations (1987) p 184.

95 Report of the Company Law Committee (June 1962, Cmnd 1749), paras 80 and 85.

96 Nigeria Law Reform Commission, supra n 94, p 184 . S 186 (1) of the Act imposes the age of 21 as the minimum age for appointment. 
fraudulent directors to find their way to boards with the consent of the courts. ${ }^{97}$

Given that there are many directors who are involved in repeat offences, the period of disqualification of five years is insufficient.

\section{Procedure For Disqualification}

In Kenya, application for a disqualification order can be made by the Official Receiver, liquidator of the company or by a person who is or has been a member or creditor of the company. ${ }^{98}$ Enabling creditors and members to make applications for disqualification enhances the process for the disqualification of miscreant directors, especially where the Attorney General would not otherwise take action due to lack of independence. However, given that the ability of creditors and members to make an application might be constrained by lack of financial resources, a public independent body might protect their interests more effectively.

In the UK, the Secretary of State is empowered to make an application for disqualification. ${ }^{99}$ However, if the company in question is in compulsory liquidation, the Secretary of State may direct the Official Receiver to make the application. ${ }^{100}$ Similarly, the Australian Securities and Investments Commission can also apply to court for disqualification orders. ${ }^{101}$

The Ghanaian Code provides that such an application can only be made by the Registrar, Official Trustee, or by the liquidator of any body corporate. Professor Gower ${ }^{102}$ recommended this measure in order to prevent malicious applications. Although the adoption of such a provision in Kenya might curb malicious prosecution to some extent, it is also possible for the provision to

97 It also sought to incorporate art 87 of Table A in relation to vacation of office. Art 87 provides for a director to vacate office if he does not take up his shares after the required period, when he becomes bankrupt, he becomes of unsound mind, he resigns, he is absent for more than six months without permission of the other directors. See Nigeria Law Reform Commission, supra n 94, p 185.

98 S 189(4)

99 CDDA, s 7(1)(a).

$100 \mathrm{~S} 7(1)(\mathrm{b})$. The UK's Cork Committee, Report of the Review Committee on Insolvency Law and Practice, Chairman Sir Kenneth Cork (1982, Cmnd) recommended that apart from the Secretary of State and the Official Receiver, liquidators and creditors should be permitted to make applications, as limiting the applications to the Insolvency Service was considered inadequate due to the fact that the Service might not have enough information about directors, especially when the company is wound up voluntarily and therefore the Official Receiver is not involved. Although liquidators, administrators and receivers are required to report to the Secretary of State on the conduct of directors, the quality of information is not always of the right quality. Another factor that would affect the effectiveness of Insolvency Service is the quantity and quality of resources utilised to enforce the provision. See National Audit Office, Company Director Disqualification (HMSO, 1993).

101 Under the Corporations Act 2001, ASIC may apply for disqualification of a person: for contravening a civil penalty provision (s 206C), "if within the last 7 years, the person has been an officer of two or more corporations when they have failed" (s 206D).

102 He drafted the Final Report of the Commission of Enquiry into the Working and Administration of the Present Company law in Ghana, 1961. 
restrict the number of persons who institute proceedings to the detriment of creditors. Since government interference in the duties of public officials has been common in the past, there is a danger of fewer cases being brought to court if the range of persons who can apply is not widened. ${ }^{103}$

In Kenya, the Registrar, as an official in the office of the Attorney General, has been less likely to enforce the disqualification provisions due to political interference. ${ }^{104}$ In the past, this has been clearly illustrated by several cases.

First, the past investigation of the Attorney General by the Parliamentary Public Investments Committee over an alleged failure to prosecute persons named in corrupt deals lends credence to lack of independence on his part. ${ }^{105}$

Secondly, the Attorney General was reluctant to prosecute those implicated in the Goldenberg fraud despite the fact that the Government lost $\$ 400$ million in public funds to Goldenberg International Ltd, trading gold and diamonds that Kenya did not produce. ${ }^{106}$ Although some directors have been prosecuted, some senior government officials in charge of the Ministry of Finance and the Central Bank have not been investigated. ${ }^{107}$

Thirdly, the Ninth Report of the Public Investments Committee recommended that the Registrar of Companies should be dismissed over a transaction in which the former Kenya Posts and Telecommunications (KPTC) irregularly lost $6,569,345$ Kenyan Shillings (£65,693). The Registrar was accused of failing to avail himself of information on the transaction in which KPTC bought 196 maisonettes at 64,680,000 Kenyan Shillings $(£ 646,800)$ and then sold them for the same amount to the Office of the President six years later. The failure on the part of the corporation to include an amount of $6,569,345$ Kenyan Shillings $(£ 65,693)$ in respect of legal fees led to a direct loss of the same amount to the corporation. ${ }^{108}$

Fourthly, the lack of political will by the former government to enforce disqualification provisions can also be discerned from a recent proposal by the Attorney General which sought to grant amnesty to individuals who had committed economic crimes before December 1, 1997. The implementation of the proposal, which was contained in the Anti-Corruption and Economic Crimes Bill 2000, would have had grave implications on corporate governance, as companies would not be able to recover money from

103 Leigh, "Disqualification Orders in Company and Insolvency Law" (1986) 7 Co Law 179, at 182.

104 "Anti-Corruption, Economic Crimes Bill Debate Rages", East African Standard, 21 July 2001 and "A-G in Spotlight for Sloppy Drafts", East African Standard, 25 July 2001.

105 Supra n 14.

106 Investigative series by Sarah Elderkin in the Daily Nation, 30 July - 6 August 1993.

107 Holman \& Wrong, "Moi Weighs Tough Corruption Probe", Financial Times, 28 July 1997.

108 “Ng'eny: I will not Resign” Daily Nation, 19 July 2000. 
miscreant directors. ${ }^{109}$ Besides, some cases, which are pending in court, against directors would come to an end. ${ }^{110}$

The fact that the Attorney General favoured the granting of amnesty to errant persons rather than investigating the offences and subsequently seeking the disqualification of those, for instance, responsible for companies' fraud is a clear indication of the interests that he was protecting. However, in spite of the possible drawbacks that might arise as a result of the implementation of the amnesty clause, the clause might also have some considerable benefits. First, given that the prosecution of past economic crimes might take many years to finalise, the implementation of the amnesty clause would enable the courts to deal more effectively with present economic crimes. ${ }^{111}$ Second, the clause might streamline the transition process by making individuals less apprehensive of losing power and wealth as a result of a comprehensive reform of the law and less likely to try to cover up the past. ${ }^{112}$

\section{Enforcement Of Disqualification Orders}

The implementation of a disqualification framework would hardly be effective without reliable enforcement mechanisms. To satisfy the objectives of disqualification orders, the Act makes a disqualified person who gets involved in the management of a company personally responsible for the debts of the company incurred while he was so involved. The responsibility attaches where it appears in the course of winding up that any business of the company has been carried on with intent to defraud creditors of the company or for any fraudulent purpose. ${ }^{113}$

\section{Limited and Conditional Orders}

The Act does not make provision for limited and conditional orders. The court therefore either imposes an absolute disqualification order or makes no disqualification order. Limited and conditional orders may be useful in

109 Although the Bill undermined donor institution conditions to the Government, the IMF supported the Bill. See "Amnesty Proposal Angers Opposition" Sunday Standard, 15 July 2001 .

110 According to the Bill, the amnesty would not apply to persons who were under investigation or were prosecuted by the former KACA, the A-G or the police for corruption related offences prior to 22 December 2000. It was also not meant to apply in the cases of offences committed by persons who were not in Kenya or against whom a warrant of arrest was outstanding on that date. See "Amnesty Proposal Angers Opposition”, East African Standard, 15 July 2001.

111 The Attorney General reckoned that it would take between ten and twenty years to work through past economic crimes. See Ochieng, "Call for Amnesty Team on Graft and Clashes", Daily Nation, 2 August 2002; Wachira, "Repent, Amnesty Seekers are Told", East African Standard, 2 August 2002.

112 The initiatives of the Truth and Reconciliation Commission in South Africa arguably enhanced the political transition process.

$113 \mathrm{~S}$ 323(1). In the UK, a person who acts or who is willing to act on the instructions of a person he knows to be disqualified can also be disqualified under CDDA, s 15. S 214 of the UK Insolvency Act 1986 gives the court a discretion to declare, on the liquidator's application, that a director be liable to contribute to an insolvent company's assets where he is guilty of wrongful trading. The court may also order disqualification for up to fifteen years. See Insolvency Act 1986, ss 213 -214; Hicks, supra n 6, at 46. 
instances where the court feels that it may, for instance, be appropriate to disqualify a director from a public company and not a private one ${ }^{114}$ in order to safeguard commercial interests. ${ }^{115}$ Therefore, where damage to the company is not apparent, conditional disqualification orders are useful because they allow the courts to balance the interests of the public, employees and the director in question and, in turn, encourage enterprise and protect creditors at the same time. Thus, where the courts are reluctant to impose absolute disqualifications due to their harsh consequences, they might be far more amenable to making limited and conditional orders. For instance, the UK courts can give directors leave to act under certain circumstances. ${ }^{116}$ It is possible for leave to act to be utilised as a limited disqualification order where a director is allowed to serve in certain capacities only. ${ }^{117}$ Similarly, Australian courts may impose such conditions or limitations as they think fit. ${ }^{118}$ Thus, the courts can protect creditors effectively by use of conditional orders rather than the far-reaching absolute disqualification orders.

\section{Undertakings}

In view of the delay problem in the Kenyan courts, Kenya might need to adopt a disqualification regime that does not clog up the court system. The adoption of undertakings by directors, for instance, would enable disqualification proceedings to be settled without reference to the courts. The directors would undertake not to be involved in the management of companies for a specific period of time. Such undertakings have already been adopted in the UK. The Insolvency Act 2000 empowers the Secretary of State to accept the undertaking of a director without requiring him to

114 Hicks, ibid, at 42.

115 In Re Majestic Studios Ltd [1989] BCLC 1, Mervyn Davies J allowed a director to continue trading after a disqualification order on condition that he was accountable to an independent assessor. In so doing the court was able to save fifty jobs which were at risk.

116 Under CDDA, s 17. In Re Lo-Line Electric Motors Ltd [1988] 3 WLR 26 a director was disqualified for a three year period but permitted to remain as a director of two companies so long as a named qualified accountant remained a director of the company. In Re Majestic Studios Ltd [1989] BCLC 1, Mervyn Davies $\mathbf{J}$ allowed a director to continue trading after a disqualification order on condition that he was accountable to an independent assessor. Such conditions are not different from the conditional orders given in other jurisdictions. See Hicks, supra n 35, at 247.

117 Hicks, ibid.

118 S 206G (1) of the Corporations Act 2001 enables the courts to grant leave to manage "corporations, particular class of corporations or a particular corporation." Under s 206G (2) the court determines the conditions and exceptions to accompany the leave. In Re Magna Alloys \& Research Pty Ltd (1974-76) 1 ACLR 203 a person was given leave to take part in the management of three specified companies when their boards were controlled by independent non-executive directors. Similarly, in Re Leomond Properties Pty Ltd (1983) 1 ACLC 1370 leave to be a director of seven companies was given following conviction for handling stolen crucifixes. In Re Minimix Industries Ltd (1982) 1 ACLC 511 a New Zealand court gave a person leave to be a manager of a specified company so long as he would not be signing cheques on behalf of the company. 
admit the actual basis of disqualification. While such undertakings might be expedient and cheaper on the public purse, they might pose a problem in that directors might accept a period of disqualification to avoid the cost burden of defending disqualification proceedings. ${ }^{119}$ Besides, the Insolvency Service might be tempted to accept undertakings in order to achieve the policy objective of disqualifying many directors. ${ }^{120}$

\section{Register of Disqualified Persons}

Whilst Kenya has no provision for a register of disqualification orders, the Ghanaian Code requires the Registrar to publish a register of disqualified persons in the Gazette and maintain it for the purposes of public inspection. ${ }^{121}$ Similarly, the UK Secretary of State maintains a register of disqualification orders, ${ }^{122}$ which is open to inspection free of charge. ${ }^{123}$ The court sends the particulars of the order to the Secretary of State for entry in the register. In addition, any variation and grant of leave to act must be communicated to the Secretary of State. ${ }^{124}$ Similarly, section 243 of the Australian Corporations Law requires the Australian Securities and Investments Commission to keep a publicly available register of disqualified company directors.

In Kenya, as there is no publication, it is not possible to enforce disqualification orders adequately, as a director might secretly continue to act. To ensure effective enforcement of disqualification orders, there is need to publicise the orders given by the courts.

\section{CONCLUSIONS}

The disqualification regime in Kenya fails significantly to deter directors who might be tempted to engage in activities that are detrimental to the wellbeing of a company. Although the present provisions do provide for disqualification of directors, they are not as effective as they might be. Some provisions in the other jurisdictions discussed above are clearly more stringent than the Act. Kenya needs to broaden the scope of provisions, offences, and grounds covered by the Act in order to prevent errant directors from finding their way into boardrooms, and to stamp out corruption.

The disqualification framework only enables a director to be disqualified on the basis of fraud when a company is a going concern. Thus, a director cannot be disqualified on the basis of breach of duty, unfitness, and failing to

119 Walters, "Directors Disqualification: The Vice-Chancellor's Address to the Chancery Bar Association" (2000) 21 Co Law 90.

120 Walters, "Bare Undertakings in Directors Disqualification Proceedings: The Insolvency Act 2000, Blackspur and Beyond" (2001) 22 Co Law 290, at 297.

$121 \mathrm{~S} 186$ (7) provides that "where any order is made or leave is granted under this section the court making the order or granting leave shall forward a copy to the Registrar who shall cause a summary thereof to be published in the Gazette. The Registrar shall maintain a register of orders made under this section and shall enter thereon particulars of each order and any leave granted and such register shall be open to the inspection of any person."

122 This was introduced in the UK by the Companies Act 1976.

123 CDDA 1986, s 18. Similar provisions exist in Australia, see Corporations Act 2001, s 1274AA.

124 S. Mayson, supra n 30, p 727. 
file returns. A director can only be disqualified, under section 189, for breach of duty when a company is in the course of winding up. This does little to raise the standards of the conduct of directors and to protect the public from miscreant directors. This provision would be more of a deterrent if it also covered unfitness of directors when the company is a going concern.

Although creditors and shareholders can make applications for disqualification, ${ }^{125}$ their interests might be compromised when their financial resources are constrained. This problem might be resolved by establishing a publicly funded body with the mandate to make such applications. The body ought to be independent from the political establishment so as to be effective.

A public register of disqualification orders would offer more protection to creditors and the general public because they would be in a position to register their protest where a disqualified person manages companies. The use of limited or conditional disqualification orders by the courts as opposed to absolute prohibitions would serve all stakeholders well because they would give courts some flexibility, which would protect both the interests of the creditors and commercial interests.

Whilst broadening the scope of disqualification would go a long way to regulating directors more effectively, it is worth noting that some stringent provisions, such as automatic disqualification, might punish directors far too much in spite of their usefulness to creditors. 